\title{
Foreign Capital Flows as Factors of Economic Growth in Bulgaria, Czech Republic, Hungary and Poland
}

\author{
T. Rodionova ${ }^{1}$, S. Yakubovskiy ${ }^{1} \&$ A. Kyfak ${ }^{1}$ \\ ${ }^{1}$ Department of World Economy and International Economic Relations, Odessa I. I. Mechnikov National University, \\ Odessa, Ukraine \\ Correspondence: T. Rodionova, Ph.D., Associate Professor, Department of World Economy and International \\ Economic Relations, Odessa I. I. Mechnikov National University, Odessa, Ukraine. E-mail: t.rodionova@onu.edu.ua
}

Received: November 5, 2019

Accepted: November 15, 2019

Online Published: December 22, 2019

doi:10.5430/rwe.v10n4p48

URL: https://doi.org/10.5430/rwe.v10n4p48

\begin{abstract}
While foreign investment is generally associated with economic growth, it can also pose significant risks to the economies of the recipient countries. An empirical study is carried out to test the causality between various forms of capital inflows and economic growth of four emerging market countries of Central and Eastern Europe: Bulgaria, the Czech Republic, Hungary and Poland. Using the vector autoregression framework it is found that prior to the crisis events in the world economy and euro area capital inflows, especially foreign direct investment, played significant role in boosting economic growth. However, afterwards there is no evidence of such impact and the reverse trend is observed: now economic growth is the factor driving capital inflows, again, mainly direct investments, to the countries. Also, as a result of the steady increase in value of the accumulated assets possessed by foreign investors in national economies negative effects of attracting foreign capital could be observed, which take the form of high volumes of repatriated profits, exceeding received investment and posing new threats for national economies.
\end{abstract}

Keywords: capital flows, economic growth, balance of payments, emerging markets, vector autoregression (VAR)

\section{Introduction}

The global financial crisis and the euro zone debt crisis have revived the debate about the feasibility of financial integration and the attraction of various forms of foreign investment, both in advanced economies and in emerging markets. Thus, current crisis phenomena give a new impetus to the empirical revision of the link between international capital flows and economic growth. In general, it is necessary to study the impact of one or another structure of external financial liabilities on the economies of countries receiving foreign investments, since the form of attracted investment determines servicing corresponding debt obligations. This paper sheds light on the impact various forms of capital inflows have on the economic growth of the four countries of Central and Eastern Europe: Bulgaria, the Czech Republic, Hungary and Poland. The choice of these countries is grounded by their fairly rapid and efficient integration into the European Union, the preservation of their own currency and the corresponding ability to implement a relatively independent own monetary policy, successful fiscal policy, which enabled the countries maintain a safe level of government debt.

According to (Ajeno, 2003), the key factor underlying the internationalization of financial markets was the growing globalization of investment in order to seek higher profits and opportunities for diversification of risks on an international scale. Investment assets in their forms according to the classification of the balance of payments are divided into direct and portfolio investments, foreign investment loans, loans and deposits that belong to the category of other investments. Foreign resources can be further classified as debt-creating obligations and as ownership-type, nondebt-creating. Debt financing creates an obligation to pay out principal and interest to a foreign creditor, while the nondebt is realized through the acquisition of property and, thus, gives the right to receive proceeds from such assets (Komáromi, 2008).

Non-debt capital inflows can take the form of foreign direct investment or portfolio investment in equity. It can be in general classified as equity capital. In the context of assessing the resilience of external imbalances, the funding structure comes to the fore. It is generally considered that one type of capital source is more beneficial from the point of view of the recipient country than other forms of capital that can exacerbate the country's vulnerability. Prasad, 2011, proves that FDI and portfolio investments in equity are the most desirable forms of capital, as the external debt of these 
countries is increasingly denominated in their national currencies. If the value of such investments falls, foreign investors carry part of capital and currency risks. FDI bring risks to foreign investors, since the latter lack the possibility of a rapid exit from the market. In addition, they bring more benefits to the recipient country, as they are associated with greater commitments and long-term investment.

It is believed that non-debt financing has a number of positive features. In particular, FDI is considered less liquid and, therefore, is more stable form of financing than debt instruments, especially during periods of "sudden stops". In addition, FDI can accelerate economic growth in the country through appropriate positive externalities (technological upgrades, managerial skills, access to new markets, etc.). Nevertheless, it is important to recognize that most of the FDI benefits described above are related to the activities of foreign companies, rather than specific means of financing (direct capital is only one of the possible ways of financing the company's activity). Nevertheless, due to the asymmetry of information, direct investors require higher returns in the event of a higher uncertainty (risk) than debt lenders (Komaromi, 2008). The undeniable advantage of FDI over debt financing is that dividend payments are pro-cyclical. Consequently, during the economic downturn, servicing of such financing may also decrease. On the contrary, servicing of debt can become risky and more expensive (an increase in interest) as a result of economic crisis. One recent empirical study found that comparing the direct foreign direct investment income in Hungary between 1995 and 2010 with alternative ways of external financing (portfolio investment and foreign loans), FDI proved to be more beneficial as it contributed to the increase in GNP by 6-14\%. Nevertheless, it was also found that the cost of servicing FDI was higher than that of alternative financial flows (Balatoni and Pitz, 2012). However, the benefits of this channel of financing may be weakened by the fact that foreign owners react to the slowdown of the domestic economy by reducing the share of reinvested earnings. Consequently, the impact of FDI on the host economies cannot be characterized as strictly positive or negative. (Yakubovskiy, 2002) highlights the significant risks for the host economies of attracting FDI: as multinational corporations are interested in increasing revenues and production volumes within their own corporate structure, they increase sales of their own products issued outside of the host countries through the network of their foreign subsidiaries. This leads to an increase in imports of FDI-recipient countries, which significantly impairs their trade balances, and in some cases, the balance of services. There is also a constant repatriation of foreign investment income from the countries. Thus, the growth of the productive potential of the country through FDI is justified only when these investments stimulate the long-term economic development of the recipient country as a whole, increase the international competitiveness of its national production, improving the trade balance. On the other hand, the outflow of funds through repatriation of profits may exceed the size of the invested capital, which is detrimental to the national economy.

Many studies explore the influence of foreign investments on the development of the specific economies. The impact of foreign investments on the dynamics and structure of the balance of payments and international investment positions of Romania and Ukraine during 2014-2017 have been determined by (Sandru and Yakubovskiy, 2018). Authors focus their attention to the impact of FDI on European economic integration (Beer, et al., 2017) and disintegration processes (Sydorova and Yakubovskiy, 2017), role of FDI in national innovation potential development (Lomachynska and Podgorna, 2018), assess the effect of foreign direct investments on exchange rate of national currencies (Combes, et al., 2011), on skilled and unskilled labor of the economies of the recipient countries (Kurtovic et al., 2016) and on the development of national banking systems (Yakubovskiy, et al., 2018), analyze the impact of the global financial crisis on the dynamics of GDP and FDI (Simionescu, 2016).

Many studies have highlighted that most developed countries rely on external financing in the form of debt, which makes up a significant share of the total net external liabilities (Kinda, 2010). First of all, debt financing from abroad influences public authorities. Households cannot borrow directly from abroad, but also as companies receive debt financing through intermediary credit institutions. The rapid expansion of companies from developing countries into the global debt financing market was driven by two factors: the growing demand of investors for high yielding assets and their desire to diversify investments (Tihomirova, 2011). The profitability of investments depends on the fundamentals: general state of the economy, inflation, monetary policy. The results of previous studies indicate that countries with better indicators of financial sustainability (lower inflation, higher propensity to invest, stable real exchange rate, etc.) attract more investment (relative to GDP) compared to countries with lower financial stability rates (Fratzscher, 2012). According to Mann, 2010, international capital flows combined with savings and investments, international trade flows and current accounts are consistent and complementary sources of external imbalances. It is often difficult to distinguish between the current account deficit, which is the result of an increase in capital inflows, and the current account deficit as a result of the accumulation of significant external debt. First of all, it concerns transition economies that are vulnerable to large, and sometimes unforeseen shocks, and undergo significant structural changes that may affect the existence of long-term current account imbalances. (Ho-don, 2007) with the help of the 
Granger test, found that the inflow of foreign capital worsened the current account in the case of emerging market countries, while the causal link was almost not found in cases of developed countries. Yakubovskiy, 2002, proved the existence of a purely negative influence of FDI inflows to current accounts of most Central and Eastern European countries.

Research has been done by scholars to determine the overall impact of the financial account on the balance of payments on the growth of emerging market economies, but empirical literature gives a rather complicated and ambiguous evidence of the link between capital flows and economic growth. Empirical assessments are mostly promoting greater openness of the economy and the liberalization of the movement of capital. Less convincing evidence is in favour of an inflow of capital. Most studies do not provide an unambiguous assessment of the positive or negative impact of capital flows - both in general and through individual components - on economic growth. Depending on the methods used, time samples and the countries under study, the results may vary significantly. Significant contribution to the study of the impact of the financial account of the balance of payments on the economic growth of emerging market countries was made by (Shevchuk, 2008), using statistical tools for assessing the link between GDP dynamics and balance of payments accounts - OLS / VAR / VEC. Using quarterly and annual data, the impact of the financial account on the economic growth of countries in South-East Asia and Latin America was analyzed.

\section{Materials and Methods}

In general, in empirical studies, the influence of certain types of financial flows on the dynamics of GDP has not received enough attention. Given the heterogeneous nature of capital flows, it is inappropriate to combine them to assess the impact of capital flows on economic growth. FDI and portfolio investment in equity are fundamentally different, since the former are associated with participation in the management of companies, while the latter are not. Both forms of capital flows differ from external debt, which creates obligations that must be repaid. Thus, there is no reason to argue that different types of capital flows have the same effect on economic growth. Due to the fact that the mutual causality between GDP and capital flows is sufficiently justified, it is appropriate to use the vector autoregression (VAR) framework, the advantage of which is a systematic way to capture the rich dynamics of time series, as (Stock and Watson, 2017) argue, taking into account the correlation between the indicators and the ability to determine the weight of the individual components in changes in the studied indicators. The estimation of the least squares (OLS - ordinary least squares), which is widespread in regression analysis, does not allow for adequate consideration of the mutual causality, the existence of which is possible in the studied time series.

To study the causality between flows of foreign capital (direct, portfolio and other investments) and GDP, the following model of VAR was used:

$$
\begin{gathered}
G D P_{t}=\alpha_{1}+\sum_{i=1}^{p} \beta_{1 i} I N V t y p e_{t-i}+\sum_{i=1}^{p} \gamma_{1 i} G D P_{t-i}+\varepsilon_{1 t} \\
I N V \text { type }_{t}=\alpha_{2}+\sum_{t=1}^{p} \beta_{2 i} G D P_{t-i}+\sum_{t=1}^{p} \gamma_{2 i} I N V t y p e_{t-i}+\varepsilon_{2 t}
\end{gathered}
$$

where INVtype $t$ - type of foreign capital (direct, portfolio and other investments).

Empirical estimates have been obtained for quarterly data from individual countries. Due to the fact that data in different countries is not homogeneous, it would be inappropriate to use aggregation methods such as panel regressions that do not allow for the consideration of important differences between individual countries, which may lead to biased estimates of coefficients. For empirical estimations, the logarithms of GDP indicators and incoming foreign capital flows (separate models for studying the impact on GDP of direct, portfolio and other investments) were used from the Eurostat, National central banks and statistical offices, the IMF International Financial Statistics databases for 4 CEE countries - Bulgaria, Poland, Hungary and the Czech Republic (quarterly data for the period 2000-2018). For portfolio and other investments, the logarithm was not used because of the large number of negative values. Also, some exogenous variables were used in the models, which took into account external factors: logarithms of consumer price inflation, real exchange rate, stock index (for specification with portfolio investment only), and money market rate (for FDI and other investment specifications). The number of lags in each model was selected to minimize the Schwarz and Akaike criteria. The stability of the VAR has been verified: all auto-regression roots are within the unit circle and the LM autocorrelation test did not detect serial correlation of the residuals, indicating the stability of the model.

In order to distinguish the impact of the global financial crisis and the euro zone crisis on the development of the selected CEE countries there will be assessed two periods: 2000-2011, when the integration of these countries into the 
EU was the most dynamic, and the period from 2011 to 2018, when the outcome of the two crises was the decline of the economic growth and inflow of foreign capital. Therefore, in general, 24 vector autoregressions will be constructed. An important component of the VAR methodology is the Granger causality test, which provides an adequate statistical toolkit for identifying the mutual causality of variables. Within the framework of vector autoregression of time series, mutual causality was tested separately between each type of foreign capital flows (FDI, portfolio and other foreign investments) and GDP of countries. According to preliminary studies, the inflow of foreign capital may have a dual effect on the development of national economies in emerging markets. On the one hand, foreign investments, primarily direct, stimulate an increase in the efficiency of enterprises in national economies, on the other hand, lead to an outflow of capital from national economies. That is why (Rodionova, 2013), for a more comprehensive assessment of the implications of attracting foreign capital, introduced a new economic indicator, the "coefficient of coverage of foreign investments", which is the ratio of total income repatriated by foreign investors in the corresponding cumulative financial account inflows:

$$
\text { Cover }^{x}=\frac{\sum I N C d_{t}^{x}}{\sum x l_{t}}
$$

where Cover - coefficient of coverage of foreign investments of type $\mathrm{x}$ direct, portfolio and other investments) for a specific time period.

The coefficient of coverage of foreign investment can be calculated separately for each year as a share of the investment income repatriated by investors in the foreign capital received by the country (the sum of liabilities for FDI, portfolio and other investments in the financial account). This coefficient can also be used as an indicator of instability in the country. The high level of profitability of foreign private capital has serious negative consequences for the economy during the crisis, and therefore governments should pay attention to the analysis of the sustainability of flows of such capital in order to take timely economic measures to stabilize these flows.

\section{Results and Discussion}

The results of the Granger test in Table 1 support the hypothesis of the influence of foreign investment flows on the GDP of countries in the period from 2000 to 2011.

Table 1. Granger's test for gross domestic product (GDPt) and capital inflows from 2000 to 2011 (FDIt, PIt, OIt - direct, portfolio and other investments respectively)

\begin{tabular}{|c|c|c|c|c|c|}
\hline \multirow[t]{2}{*}{ Country } & \multirow[t]{2}{*}{ Indicators } & \multicolumn{4}{|c|}{ Lags } \\
\hline & & GDP & FDI & PI & OI \\
\hline Bulgaria & GDP & $5.09(0.27)$ & $11.63(0.02)^{b}$ & $2.19(0.33)$ & $7.67(0.10) \mathrm{c}$ \\
\hline (2000Q2 & FDI & $0.63(0.72)$ & & & \\
\hline \multirow[t]{2}{*}{ 2011Q3) } & PI & $19.92(0.00)^{\mathrm{a}}$ & & & \\
\hline & OI & & & & \\
\hline Poland & GDP & & $14.31(0.00)^{\mathrm{a}}$ & $2.89(0.57)$ & $22.63(0.00)^{\mathrm{a}}$ \\
\hline (2000Q1 & FDI & $11.37(0.02)^{\mathrm{b}}$ & & & \\
\hline \multirow[t]{2}{*}{ 2011Q3) } & PI & $9.82(0.04)^{\mathrm{b}}$ & & & \\
\hline & $\mathrm{OI}$ & $2.10(0.71)^{\mathrm{a}}$ & & & \\
\hline Czech Republic & GDP & & $9.61(0.00)^{\mathrm{a}}$ & $6.54(0.16)$ & $16.36(0.00)^{\mathrm{a}}$ \\
\hline (2000Q1 & FDI & $2.34(0.31)$ & & & \\
\hline \multirow[t]{3}{*}{ 2011Q3) } & PI & $10.87(0.02)^{\mathrm{b}}$ & & & \\
\hline & OI & $12.66(0.01)^{\mathrm{a}}$ & & & \\
\hline & GDP & & $5.12(0.07)^{\mathrm{c}}$ & $8.95(0.02)^{b}$ & $6.36(0.04)^{\mathrm{a}}$ \\
\hline Hungary & FDI & $2.26(0.32)$ & & & \\
\hline (2000Q2 & PI & $3.04(0.38)$ & & & \\
\hline 2011Q3) & OI & $30.6(0.00)^{\mathrm{a}}$ & & & \\
\hline
\end{tabular}

Note: in parentheses p-values are given, a,b,c represent the 1,5, and $10 \%$ significance levels, respectively. 
Among the countries studied, GDP is influenced in most cases by FDI and external debt (other investments). There is also an effect of the GDP dynamics on the inflow of capital to the countries studied, which proves the relevance of using VAR-models for these countries. The causality of " $\uparrow$ GDP" $\rightarrow$ " $\uparrow$ FDI" means that favorable dynamics of GDP creates incentives for capital inflows. A similar study was made by scientists at the Institute for International Finance (Suttle, et al., 2012), which found that for 30 emerging economies economic growth is a key factor for capital flows. Thus, the hypothesis of the lack of FDI impact on economic growth can be rejected for all the studied countries. Influence of GDP dynamics on FDI flows can be seen in Poland. For all countries, the presence of the influence of the inflow of FDI on the dynamics of GDP has been detected. According to the Granger test, among the studied countries, practically only in Hungary, economic growth depends on portfolio investment. But according to the results of impulse response functions (Figure 1), in addition to the positive impact of portfolio investment on Hungarian GDP, one can also observe the reverse causality between portfolio investment and economic growth in the Czech Republic and Bulgaria for about a year. Regarding other investments, in almost all countries studied, except for Bulgaria, the Granger test revealed their impact on economic growth. The largest link between GDP dynamics and other investments is observed in Hungary, although the weight in the decomposition of residues is only $10 \%$, while the highest positive effect is observed in Poland, where the weight in the variance decomposition is $60 \%$. In the Czech Republic and Bulgaria, other investments improve GDP dynamics.

Considering the period from 2011 to 2018 (Table 2), it can be noted that if earlier the FDI caused the dynamics of economic growth, in the post-crisis period GDP was a factor of the inflow of capital to the countries.

Table 2. Granger's test for GDP and capital inflows from 2011 по 2018

\begin{tabular}{|c|c|c|c|c|c|}
\hline \multirow[t]{2}{*}{ Country } & \multirow[t]{2}{*}{ Indicator } & \multicolumn{4}{|c|}{ Lags } \\
\hline & & GDP & FDI & PI & OI \\
\hline & GDP & & $5.00(0.41)$ & $2.34(0.79)$ & $3.69(0.71)$ \\
\hline Bulgaria & FDI & $5.74(0.33)$ & & & \\
\hline (2011Q4 & PI & $6.33(0.27)$ & & & \\
\hline \multirow[t]{2}{*}{ 2018Q3) } & OI & $5.04(0.53)$ & & & \\
\hline & GDP & & $2.31(0.80)$ & $6.67(0.24)$ & $1.94(0.87)$ \\
\hline Poland & FDI & $10.5(0.06)^{\mathrm{c}}$ & & & \\
\hline (2011Q4 & PI & $1.98(0.85)$ & & & \\
\hline \multirow[t]{2}{*}{ 2018Q3) } & OI & $0.92(0.96)$ & & & \\
\hline & GDP & & $12.3(0.05)^{\mathrm{b}}$ & $1.95(0.92)$ & $10.01(0.07)^{\mathrm{c}}$ \\
\hline Czech Republic & FDI & $28.1(0.01)^{\mathrm{a}}$ & & & \\
\hline (2011Q4 & PI & $3.25(0.77)$ & & & \\
\hline \multirow[t]{2}{*}{ 2018Q3) } & OI & $2.46(0.78)$ & & & \\
\hline & GDP & & $1.75(0.88)$ & $9.86(0.07)^{\mathrm{C}}$ & $4.83(0.43)$ \\
\hline Hungary & FDI & $8.98(0.10)^{\mathrm{c}}$ & & & \\
\hline (2011Q4 & PI & $2.44(0.78)$ & & & \\
\hline 2018Q3) & OI & $9.65(0.08)^{\mathrm{c}}$ & & & \\
\hline
\end{tabular}

Note: in parentheses p-values are given, a,b,c represent the 1,5 , and $10 \%$ significance levels, respectively.

For additional verification of the obtained results, the corresponding impulse response functions were used to determine the temporal effect of the variables on the resulting indicator, and variance decomposition, which reflects the relative weight (value of influence) of three different sources of foreign investment (direct, portfolio, etc.), was used in changes in GDP of the countries. Impulse response functions for the VAR models of the countries under study show that in the period from 2000 to 2011, the impact of FDI on economic growth was observed except for the Czech Republic, where there was reverse causality between FDI and GDP (Figure 1).

The variance decomposition from 2000 to 2011 reveals that the greatest weight of FDI in the decomposition of residuals is observed in Poland - up to 50\%. In Hungary and the Czech Republic, the weight in the variance decomposition is up to $20 \%$. In Bulgaria, the share of FDI in variance decomposition is the smallest - $10 \%$. 


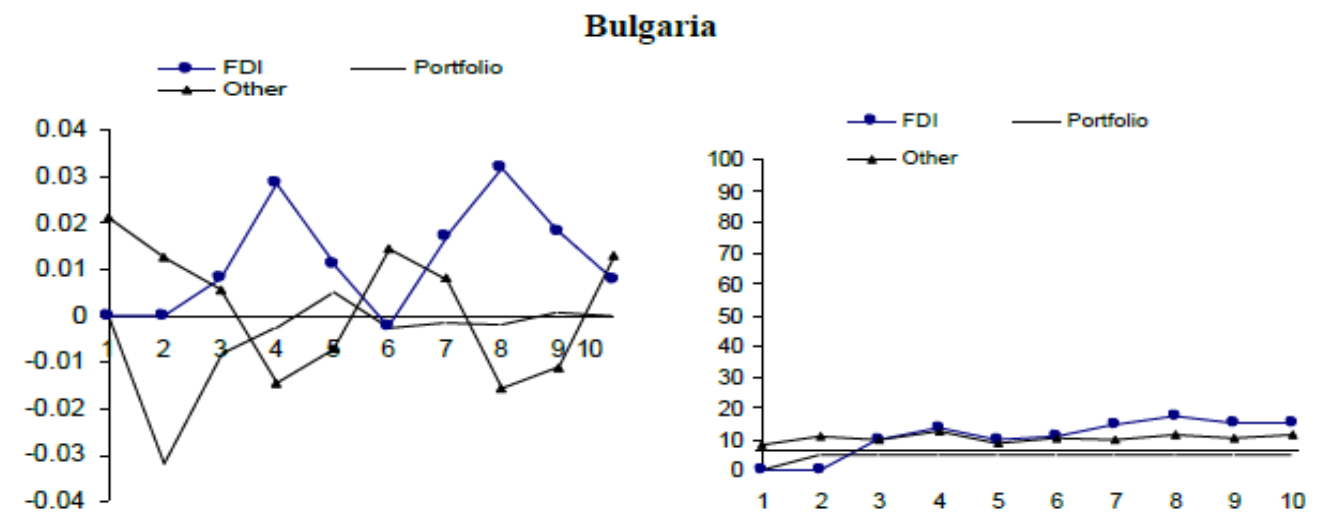

\section{Hungary}
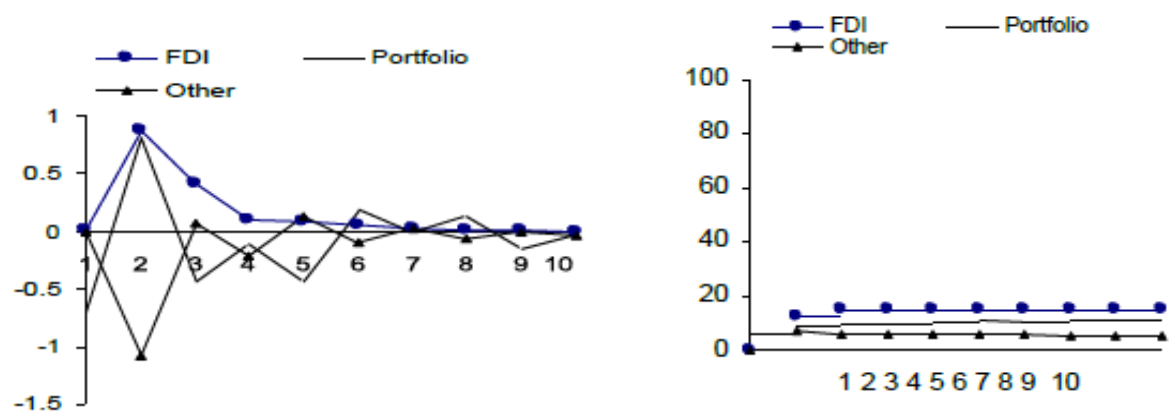

\section{Poland}
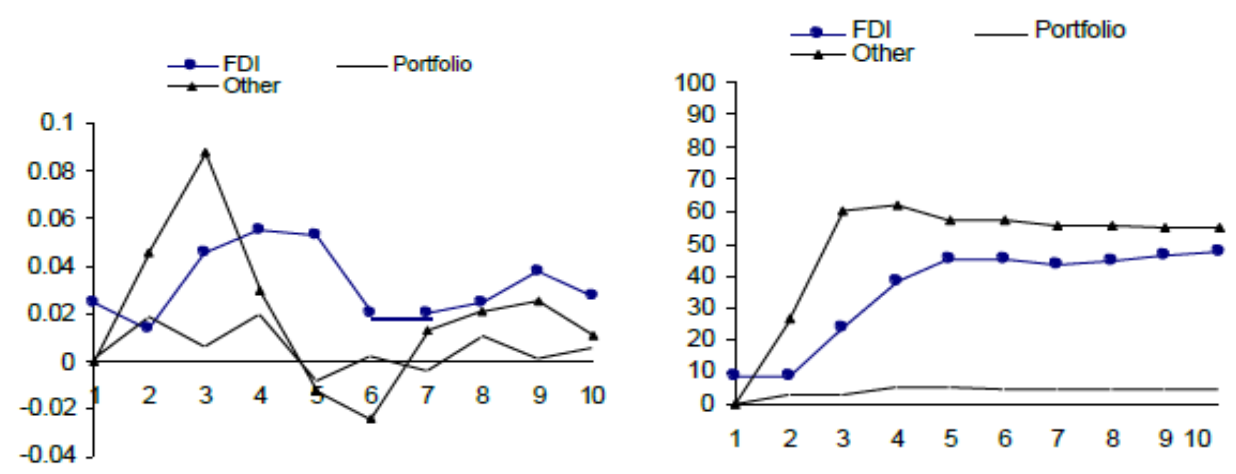

\section{Czech Republic}
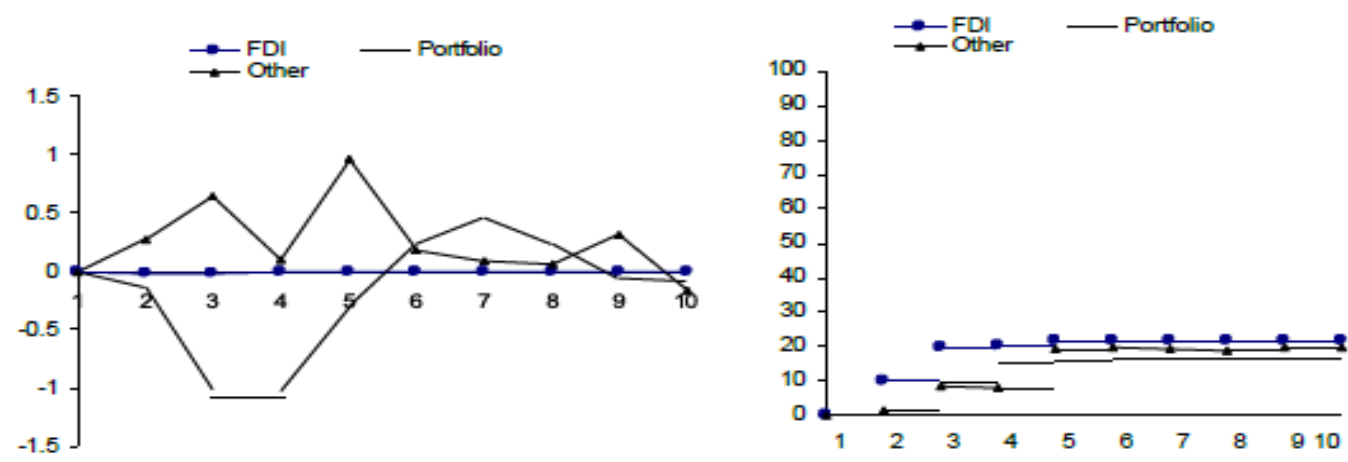

Figure 1. Impulse responses and variance decomposition of GDP to the various capital inflows in the period 2000-2011 (based on VAR-models) 
Further, according to the significant results of the Granger test presented in Table 2, the effect of GDP on FDI of the countries is considered by simulating impulse response functions and decomposing the variance of VAR models for the period from 2011 to 2018 (Figure 2). In Poland and Hungary, the dynamics of GDP leads to the inflow of FDI to the countries, whereas in the Czech Republic, the negative impact is initially observed. Regarding the importance of decomposition of residuals, only in the Czech Republic there is a significant contribution of GDP - up to 40\%, in Hungary and Poland - less than $40 \%$.
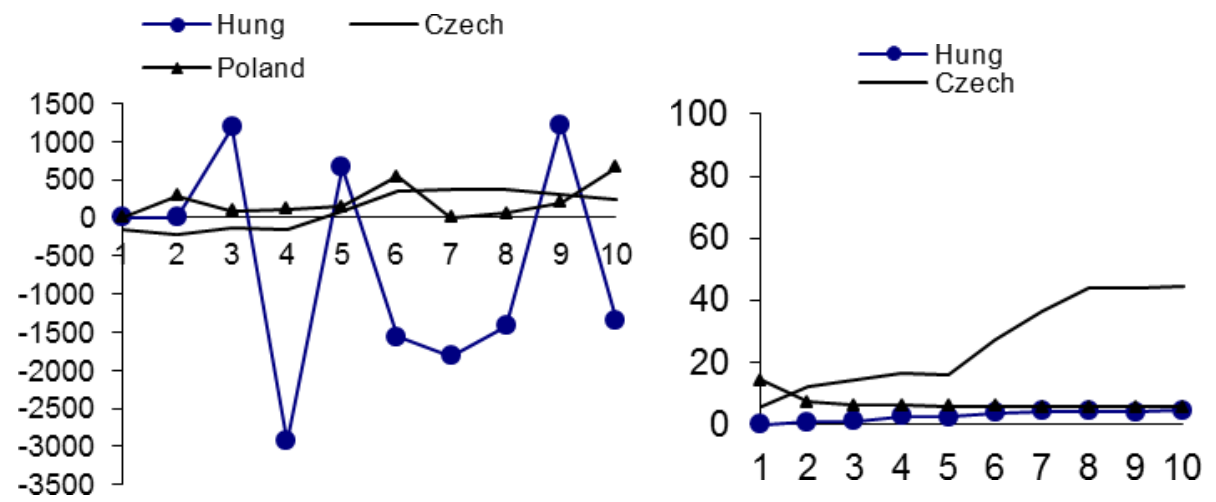

Figure 2. Impact of GDP on the FDI dynamics in the period of 2011-2018 (based on VAR-models)

The obtained empirical results are summarized in Table 3. In general, the main conclusions of (Shevchuk, 2008) study of the impact of aggregated capital inflows (financial accounts) on the country's economic growth have been confirmed. Between 2000 and 2011, the countries' economic growth was driven by an active inflow of capital, especially foreign direct investment. The beneficial effects of capital inflows are realized almost entirely within one year. The largest share of capital flows in the variance decomposition was observed in Poland. In the post-crisis period mainly GDP was a factor of the inflow of capital to the countries and not the other way around.

Table 3. Summary of the impact of foreign investment on the economic growth of the selected CEE countries

\begin{tabular}{lcccc}
\hline & \multicolumn{2}{c}{ Dependent Variable - } & \multicolumn{3}{c}{ GDP of the country } & Lags \\
\cline { 2 - 4 } Country & Explored period & FDI & PI & OI \\
\hline \multirow{2}{*}{ Bulgaria } & 2000Q1-2011Q4 & $\uparrow$ & $\downarrow$ & $\uparrow$ \\
\cline { 2 - 5 } & $2012 \mathrm{Q} 12018 \mathrm{Q} 3$ & - & - & - \\
\hline Poland & 2000Q1-2011Q4 & $\uparrow$ & - & $\uparrow$ \\
\cline { 2 - 5 } & 2012Q1 2018Q3 & - & - & - \\
\hline Czech Republic & $2000 \mathrm{Q} 1-2011 \mathrm{Q} 4$ & $\downarrow$ & $\downarrow$ & $\downarrow$ \\
\cline { 2 - 5 } & $2012 \mathrm{Q} 12018 \mathrm{Q} 3$ & $\uparrow$ & - & $\downarrow$ \\
\hline Hungary & $2000 \mathrm{Q} 1-2011 \mathrm{Q} 4$ & $\uparrow$ & $\uparrow$ & - \\
\cline { 2 - 5 } & $2012 \mathrm{Q} 12018 \mathrm{Q} 3$ & - & $\downarrow$ & $\downarrow$ \\
\hline
\end{tabular}

Coefficients of coverage of foreign investments for the selected countries are the following. For Bulgaria: the coefficient of coverage of direct investments for 2000Q1-2011Q4 was 31.2\%, during 2012Q1-2018Q2- 109\%; the coefficient of coverage of portfolio investment for 2000Q1-2011Q4 can not be calculated, because portfolio foreign investments assets in the country was decreased by 3.382 billion dollars during the period, while foreign portfolio investors' income was $\$ 2.236$ billion, the coefficient of coverage of portfolio investments for 2012Q1-2018Q2 was $25.5 \%$; the coefficient of coverage of other investments for 2000Q1-2011Q4 was 23.5\%, during 2012Q1-2018Q2 the coefficient can not be calculated, because during this period the assets of other foreign investments decreased by 3.373 billion dollars, while income from other foreign investments amounted to 3.219 billion dollars. 
For the Czech Republic: the coefficient of coverage of direct investments for 2000Q1-2011Q4 was 110\%, during 2012Q1-2018Q2 - 207\%; the coefficient of coverage of portfolio investments for 2000Q1-2011Q4 was 37.4\%, during 2012Q1-2018Q2 - 25.3\%; the coefficient of coverage of other investments during 2000Q1-2011Q4 was $63.1 \%$, during 2012Q1-2018Q2 - $11.2 \%$.

For Hungary: the coefficient of coverage of direct investments for 2000Q1-2011Q4 was 70\%, during 2012Q1-2018Q2 - 120\%; the coefficient of coverage of portfolio investments for 2000Q1-2011Q4 amounted to $78.3 \%$, during 2012Q1-2018Q2 could not be calculated, because the assets of the portfolio foreign investments in the country decreased by 10.199 billion euros over the period, while the income of foreign portfolio investors amounted to 14.310 billion euros; the coefficient of coverage of other investments for 2000Q1-2011Q4 was $23.6 \%$, during the 2012Q1-2018Q2 can not be calculated, because during this period the assets of other foreign investments in the country decreased by 29.855 billion euros, while income from other foreign investments amounted to 6.666 billion euros.

For Poland: the coefficient of coverage of direct investments for 2000Q1-2011Q4 was 75.6\%, during 2012Q1-2018Q2 - 166\%; the coefficient of coverage of portfolio investments for the period 2000Q1- 2011Q4 was $35.9 \%$, during 2012Q1-2018Q2 - 108\%; the coefficient of coverage of other investments for 2000Q1-2011Q4 amounted to $30.4 \%$, during 2012Q1-2018Q2 could not be calculated, because during this period, the assets of other foreign investments in the country decreased by 998 million euros, while income from other foreign investments amounted to 12.676 billion euros.

Consequently, all the countries during 2012-2018 received less foreign direct investment than income from foreign direct investment repatriated from these countries. In general, only for the Czech Republic the amount of foreign direct, portfolio and other investments received (mainly due to other investments) exceeds the amount of income from these investments that has been repatriated from the countries.

\section{Conclusion}

Thus, the results of the analysis show that the attraction of foreign capital during 2000-2011 was one of the main factors of economic growth and European integration in Poland, the Czech Republic, Hungary and Bulgaria. However, after 2011, the influence of foreign capital inflows on economic growth in the studied countries almost ceased and negative effects of attracting foreign capital could be observed, which, first of all, manifests itself in the repatriation of foreign investors' income from the economies.

The increase in the volumes of repatriated investment revenues from the economies of Poland, the Czech Republic, Hungary and Bulgaria is due to a steady increase in the value of accumulated assets in national economies that are controlled from abroad. As a result, the negative impact of attracted foreign investment on the balance of payments of the countries, primarily on current accounts, is constantly increasing. In particular, in 2017, the income of foreign direct investors in the Czech Republic by $87 \%$ exceeded the inflow of direct foreign investments in the country, in Poland - by 101\%, and in Hungary with direct investors income in 16.9 billion dollars their direct investments decreased by 13.5 billion. Therefore, in 2017, the total current account debit of the balance of payments of Poland, the Czech Republic, Hungary and Bulgaria reached the highest level for all previous historical values of the countries. A significant amount of foreign investors' income in the economies of the studied countries of Central and Eastern Europe is one of the key factors that prevents countries from switching to a single European currency because the availability of their own currency allows Poland, the Czech Republic, Hungary and Bulgaria to count on, due to devaluation, almost automatic stabilization of the balance of payments in cases of a sharp capital flight by foreign investors. In problematic countries of the euro zone - especially in Greece, Italy, Spain and Portugal, there is no such mechanism.

However, despite the existence of an internal mechanism for the balance of payments adaptation due to fluctuations in the exchange rate, the results obtained still raise questions about the existing large-scale foreign investments in Central and Eastern European countries and, possibly, the need to restrict the repatriation of capital with the help of changes in tax legislation, for example through introduction of the tax on non-reinvested income from foreign investment. However, in order to arrive at a final conclusion in further research, it is necessary to empirically determine the ratio of usefulness of attracted foreign capital, which is associated with an increase in the volume of GDP and exports of countries, and the losses from the repatriation of income from foreign investment.

\section{Conflict of interest}

The author declares that there is no conflict of interests regarding the publication of this manuscript. 


\section{References}

Agenor, P. (2003). Benefits and costs of international financial integration: theory and facts. The World Economy, 26(8), 1089-1118.

Balatoni, A., \& Pitz, M. (2012). The effect of direct investment on Hungary's gross national income. Közgazdasági Szemle, 59(1), 1-30.

Beer, C., Belabed, C.-A., Breitenfellner, A., Ragacs, C., \& Weber, C. (2017). EU integration and its impact on Austria. Monetary Policy \& the Economy, 17(1), 86-125.

Bulgarian National Bank. (2019). Balance of payments statistics. Retrieved from http://www.bnb.bg/Statistics/StExternalSector/StBalancePayments/StSearchStandard/index.htm

Combes, J., Kinda, T., \& Plane, P. (2011). Capital flows, exchange rate flexibility, and the real exchange. International monetary fund Working Paper, 1-33.

Central Bank of Hungary. (2019). Balance of payments, foreign direct investment, international investment position. Retrieved

from https://www.mnb.hu/en/statistics/statistical-data-and-information/statistical-time-series/viii-balance-of-payments -foreign-direct-investment-international-investment-position

Czech National Bank. (2019). Balance of payments statistics. Retrieved from https://www.cnb.cz/en/statistics/bop_stat/

Czech Statistical Office. (2019). Database of national accounts. Retrieved from http://apl.czso.cz/pll/rocenka/rocenka.indexnu?mylang=EN

Eurostat. (2019). Balance of payments statistics. Retrieved from https://ec.europa.eu/eurostat/web/euro-indicators/data/database

Fratzscher, M. (2012). Quantitative easing, portfolio choice and international capital flows. European Central Bank Working Paper.

Ho-don, Y. (2007). Does capital mobility finance or cause a current account imbalance?. The Quarterly Review of Economics and Finance, 47(1), 1-25.

Hungarian Central Statistical Office. (2019). National accounts, GDP. Retrieved from http://www.ksh.hu/national_accounts_gdp

International Monetary Fund. (2019). International financial statistics. Retrieved from http://data.imf.org/?sk=4C514D48-B6BA-49ED-8AB9-52B0C1A0179B

Kinda, T. (2010). Investment climate and FDI: firm-level evidence. World Development, 38(4), 498-513.

Komáromi, A. (2008). The structure of external financing: Is there a reason to worry about financing through debt?. Magyar Nemzeti Bank Bulletin, 3(1), 14-23.

Kurtovic, S., Dacic H., \& Talovic S. (2016). The effect of foreign direct investment from Austria on skilled and unskilled labor in Bosnia and Herzegovina. Business and Economic Research, 6(1), 210-223.

Lomachynska, I., \& Podgorna, I. (2018). Innovation potential: impact on the national economy competitiveness of the EU developed countries. Baltic Journal of Economic Studies, 4(1), 262-271.

Mann, C. (2010). External imbalances: costs and consequences of unsustainable trajectories. Rebalancing the global economy: a primer for policymaking. London: Centre for Economic Policy Research, pp. 43-49.

Narodowy Bank Polski. (2019). Balance of payments statistics. Retrieved from https://www.nbp.pl/homen.aspx?f=/en/statystyka/Balance_of_payments.html

National Statistical Institute of Bulgaria. (2019). Macroeconomic statistics. Retrieved from http://www.nsi.bg/en/content/11236/macroeconomic-statistics

Prasad, E. (2011). Role reversal. Finance \& Development. A Quarterly Publication of the International Monetary Fund, 48(4), 26-29.

Rodionova, T. (2013). Structural risks of foreign liabilities: impact of investment income repatriation in emerging economies. Transition Studies Review, 20(2), 119-129.

Sandru, S., \& Yakubovskiy, S. (2018). Ways to improve the efficiency of the foreign economic positions of Romania 
and Ukraine. Acta Universitatis Danubius. Economica, 14(7), 24-30.

Simionescu, M. (2016). The relation between economic growth and foreign direct investment during the economic crisis in the European Union. Zbornik radova Ekonomskog fakulteta u Rijeci, 34(1), 187- 213.

Shevchuk, V. (2008). Platizhnyi balans, ekonomichne zrostannia i stabilizatsiina polityka. [Balance of payments, economic growth and stabilization policy]. Lviv: Kalvaria. [in Ukrainian]

Statistics Poland. (2019). National accounts. Retrieved from http://stat.gov.pl/en/topics/national- accounts/

Stock, J., \& Watson, M. (2017). Twenty years of time series econometrics in ten pictures. Journal of Economic Perspectives, 31(2), $59-86$.

Sydorova, Z., \& Yakubovskiy, S. (2017). Development prospects of London as the world's financial center in the conditions of Brexit. Baltic Journal of Economic Studies, 3(4), 238-243.

Suttle, P. (2012). Capital flows to emerging market economies. Institute of International Finance. Retrieved from http://www.iif.com/emr/resources+2315.php

Tihomirova, A. (2011). Pryamye inostrannye investitsii vedushih stran ES [Direct investments of the leading EU countries]. World Economy and International Economic Relations Journal, 12, 49-56. [in Russian]

Yakubovskiy, S. (2002). Investicionnaya diyal’nist` transnatsional’nyh corporatsij ta yy vplyv na konkurentnospromojnist national'nyh economic [Investment activity of transnational corporations and its influence on the competitiveness of national economies]: monograph. Ukrainian Academy of Public Administration. [in Ukrainian]

Yakubovskiy, S., Lomachynska, I., \& Khaddad, K. (2018). Rozvytok bankivskoi systemy Avstrii v umovah globalizatsii [Development of Austrian banking system in the conditions of globalization]. Naukovyi visnyk Uzhhorodskoho natsionalnoho universytetu. Seriia: mizhnarodni ekonomichni vidnosyny - Uzhorod National University Herald. Series: International Economic Relations and World Economy, 17(2), 148-152. [in Ukrainian] 